\title{
A STUDY ON METHANE DEGRADATION LAYER EXTRACTED FROM LANDFILL MINING
}

\author{
Kaur-Mikk Pehme* \\ Toomas Tamm \\ Kaja Orupõld \\ Mait Kriipsalu \\ Estonian University of Life Sciences, Estonia
}

\begin{abstract}
Due to the harmful effect on the environment, landfill gas has to be collected and processed. One possible solution would be covering the landfill with a bioactive layer, where methane gas is oxidized.

The aim of this research is to study the possibilities of extracting material for the methane degradation layer from the landfill itself by means of Landfill Mining (LFM). Chemical and biological properties as well as hydrophysical properties like hydraulic conductivity and saturated volumetric water content of the fine fraction were measured to verify whether the material meets the requirements.

As the result of the study it appeared that the fine fraction sieved out during Landfill Mining was suitable as a methane degradation layer when mixed with amendments. The best ratio of components was found $60 \%$ fine fraction from LFM, $20 \%$ soil, and $20 \%$ matured sludge compost.

The installation of the methane degradation layer has been finished. The research continues to closely observe the result of methane degradation in full scale. While applying the knowledge obtained in this study to any other landfill it has to be kept in mind that the properties of the covering layer and the ratio of components directly depend on the properties of the fine fraction, amendments, and the parameters of the landfill.
\end{abstract}

\section{KEYWORDS}

Bioactive layer; Landfill mining; Landfill gas; HYPROP, Hydraulic conductivity, Saturated volumetric water content; Oxytop

https://doi.org/10.15626/Eco-Tech.2014.013 


\section{INTRODUCTION}

Landfill gas is a greenhouse gas that is harmful for environment. Landfills provide a significant share of the global anthropogenic methane production. Landfill gas is flammable and explosive, can contribute to landfill fires, smother vegetation and can damage the health of service personnel. Landfill gas must be collected and disposed. In a large landfill it can be profitable to produce energy from gas but it is not economic in small ones. Microbial methane oxidation is an alternative option to reduce low-level $\mathrm{CH}_{4}$ emissions by naturally occurring methanotrophs. Methanotrophs are the bacteria which decompose methane. Their main source of energy and carbon is methane which they oxidize during exothermic processes to water and carbon dioxide [10]. It is possble to decompose volatile methane by constructing specially designed methane degradation cover-layer (bicover) or making biowindows or biotraps into conventional landfill cover [4]. This kind of biocover was designed for Kudjape landfill in Estonia. Usually the cover material is brought from elsewhere and it is possible to adjust the properties of the material in advance. In this project it was decided to extract the material from the same landfill by using landfill mining technology. It is innovative solution in Estonia and rarely practiced in the world. There is lack of information if the properties of fine fraction extracted from landfill are fit to purpose as methane degradation layer. The aim of this study is to describe the fine fraction screened from landfill and how it was adapted it to meet the requirements as biocover. In order to achive the limit values set for biocover, series of laboratory and field tests were made to study physical, chemical and hydraulic propertis of fine fraction from landfill mining.

\section{LANDFILL GAS}

A large part of the greenhouse gases comes from human activity. In year 2004 methane accounted for $14.3 \%$ anthropogenic greenhouse gas emissions [5] and landfill gas is a major part of this. Shortly after deposition the organic matter of waste it starts to decompose slowly. Outcome of this process is mixture of methane $\left(\mathrm{CH}_{4}\right)$ and carbon dioxide $\left(\mathrm{CO}_{2}\right)$ which is called landfill gas [9]. The global warming potential $\left(\mathrm{GWP}_{100}\right)$ of methane $\left(\mathrm{CH}_{4}\right)$ is twentyfive times bigger than carbon dioxide $\left(\mathrm{CO}_{2}\right)$ [12]. Methane is gas without any color or odor and is lighter than air. It can ignite or explode from a spark if there is 5 to $15 \%$ methane and at least $12 \%$ oxygen by volume in the air [1].

Table 1. Composition of landfill gas [1]

\begin{tabular}{lccc} 
& Unit & Range & Average \\
\hline Methane $\left(\mathrm{CH}_{4}\right)$ & $\%$ & $35-60$ & 50 \\
\hline carbon dioxide $\left(\mathrm{CO}_{2}\right)$ & $\%$ & $35-55 \%$ & $45 \%$ \\
\hline Nitrogen $\left(\mathrm{N}_{2}\right)$ & $\%$ & $0-20 \%$ & $5 \%$ \\
\hline Oxygen $\left(\mathrm{O}_{2}\right)$ & $\%$ & $0-2.5 \%$ & $<1 \%$ \\
\hline Hydrogen sulfide $\left(\mathrm{H}_{2} \mathrm{~S}\right)$ & ppmv & $1-1700$ ppmv & 21 \\
\hline Halides & ppmv & NA & 132 \\
\hline Water vapor $\left(\mathrm{H}_{2} \mathrm{O}\right)$ & $\%$ & $1-10$ & $\mathrm{NA}$ \\
\hline Non-methane organic compounds (NMOCs) & ppmv & $237-14294$ & 2700
\end{tabular}




\subsection{Biodegradation of methane}

Methanotrophs are widespread bacteria, which decompose methane in nature. These bacteria primarily use methane as a source of energy and carbon. During exothermic processes the $\mathrm{CH}_{4}$ is being oxidized to carbon dioxide and water [10].

$$
\mathrm{CH}_{4}+2 \mathrm{O}_{2} \rightarrow \mathrm{CO}_{2}+2 \mathrm{H}_{2} \mathrm{O}+882,6 \mathrm{~kJ}
$$

Usually the methanotrophs appear in places where methane is emitted at the source (e.g. landfill) and mixes with atmospheric air [8]. Microorganisms oxidize methane in the upper zone of the cover material - a place where methane an oxygen concentration curves meet (Figure 1).

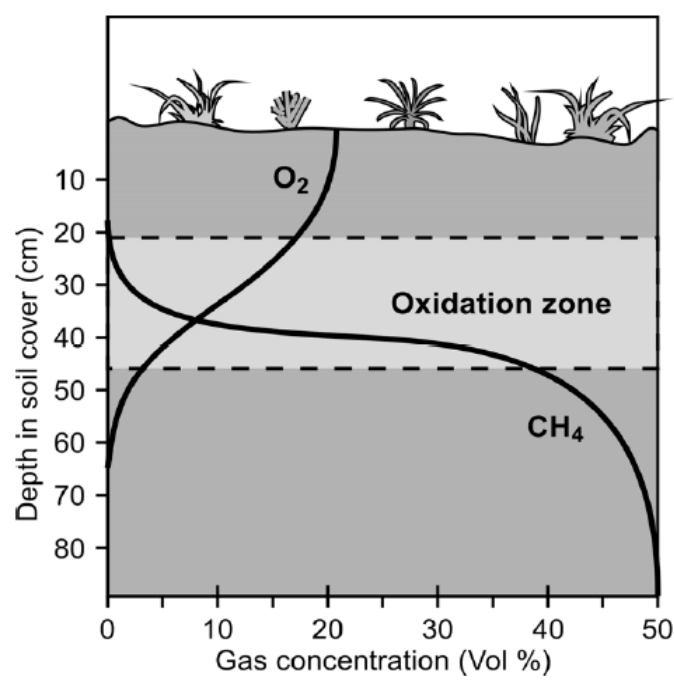

Figure 1. Idealized gas concentration profile in landfill cover [9]

\subsection{Requirements for degradation layer}

Methanotrophical organisms are quite capable of adaptation but nevertheless a suitable environment must be created. The efficiency of biocover is affected by several factors [7]

- the landfill gas loading on biocover and its fluctuations;

- the local climate i.e. temperature, rainfall and evaporation, and its effect on the temperature and moisture content of the biocover;

- the temperature of the biocover, which is affected by the temperature of the landfill gas to be treated, atmospheric temperature, rainfall, microbiological activity within the biocover, and the location of the landfill:

- the moisture content of the biocover through it profile, considering that it is affected by rainfall, evaporation, properties of the biocover material, and microbiological activity;

- the characteristics of the biocover including its stability, degradability, grain size, particle distribution, porosity, water holding capacity, hydraulic conductivity, and gas conductivity. 


\section{Linnaeus ECO-TECH'14}

Kalmar, Sweden, November 24-26, 2014

In order to have high performance methane degradation layer it should meet the requirements as in Table 2 which are interlinked and sometimes controversial:

Table 2. Requirements for methane degradation $[3,8,9,11,12]$

Pos Characteristics Unit Value Comment

\begin{tabular}{llccl}
\hline 1 & $\begin{array}{l}\text { Total organic carbon } \\
\text { (TOC) }\end{array}$ & \% DM & $>$ & $\begin{array}{l}\text { High content of nutrients and } \\
\text { organic matter }\end{array}$ \\
\hline 2 & $\begin{array}{l}\text { Carbon and nitrogen } \\
(\mathrm{C} / \mathrm{N}) \text { ratio }\end{array}$ & 15 & Favorable for bacteria \\
\hline 3 & $\begin{array}{l}\text { Respiration activity } \\
\left(\mathrm{RA}_{7}\right)\end{array}$ & $\begin{array}{c}\mathrm{mg} \mathrm{O}_{2} / 1 \mathrm{~g} \\
\mathrm{DM}\end{array}$ & $\leq 8$ & $\begin{array}{l}\text { Sufficiently stabilized organic } \\
\text { matter }\end{array}$ \\
\hline 4 & Porosity & $\mathrm{v} / \mathrm{v}$ & $60-70 \%$ & $\begin{array}{l}\text { The high porosity is required for } \\
\text { movement of gases (methane } \\
\text { and oxygen) and water within } \\
\text { biocover. }\end{array}$
\end{tabular}

\begin{tabular}{|c|c|c|c|c|}
\hline 5 & $\begin{array}{l}\text { Water binding } \\
\text { capacity }\end{array}$ & $\%$ & $>80$ & $\begin{array}{l}\text { The material should be able to } \\
\text { bind and retain moisture well }\end{array}$ \\
\hline 6 & $\begin{array}{l}\text { Hydraulic } \\
\text { conductivity (k) }\end{array}$ & $\mathrm{m} / \mathrm{s}$ & $>10^{-4}$ & \\
\hline 7 & $\begin{array}{l}\text { Water holding } \\
\text { capacity }\end{array}$ & $\mathrm{v} / \mathrm{v}$ & $35-45 \%$ & $\begin{array}{l}\text { Moisture is required to stimulate } \\
\text { biological activity. Too large } \\
\text { water content can block pores of } \\
\text { the oxidation }\end{array}$ \\
\hline 8 & Gas permeability (k) & $\mathrm{m} / \mathrm{s}$ & $>10^{-5}$ & Moderate \\
\hline 9 & Homogeneous & - & - & $\begin{array}{l}\text { Material should be well mixed } \\
\text { to reduce the direct flow of } \\
\text { landfill gas through the cover } \\
\text { layer }\end{array}$ \\
\hline
\end{tabular}

10 Good insulation capacity
At the higher temperatures, the bacteria become active. Each $10^{\circ} \mathrm{C}$ rise in temperature increases the methane oxidation two to four times. 


\section{KUDJAPE LANDFILL}

Kujdape landfill is located in Saaremaa, Estonia (58.268683, 22.538560). Kudjape landfill was used during 1970-2009 for disposing of municipal waste. Before excavations the height of the deposition area was 12 meters and it covered 4.2 hectares. There is no watertight bottom layer.

As requested by Environmental Board a $1.2 \mathrm{~m}$ thick final cover layer was requested. It had to act as methane degradation layer e.g. biocover. The mixtures of biocover was prescribed as shown in positions 1 to 5 in Table 2. For construction of gas distribution layer the $0.5 \mathrm{~m}$ thick coarser fraction of mineral material had to be used.

By dimension Kudjape landfill is small, however, it still takes $60000 \mathrm{~m}^{3}$ of material to cover the landfill with layers of gas distribution and methane degradation. Landfill geographic location put restrictions on excavation of local material. It would have been very expensive to bring it from mainland using trucks and ferries. As Saaremaa is an island with area of 2673 $\mathrm{km}^{2}$ the option to dig a big hole was excluded also. The only realistic solution was to use the fine material from the same landfill. Area of 1.9 hectares with $55000 \mathrm{~m}^{3}$ was excavated and screened to get necessary amount of material. During this process the landfill content was separated in following fractions - potential waste fuel, material that is suitable for cover layer and material that is not eligible for reuse. The last fraction was backfilled.

\subsection{Sampling}

During the excavations the content of landfill was screened with $40 \mathrm{~mm}$ drum sieve. Samples were taken from material produced by drum sieve ( $\mathrm{FF}$ - fine fraction $\leq 40 \mathrm{~mm}$ ). Naturally available soil and matured sewage sludge were also sampled as potentially valuable cover materials. Particular attention was paid to sampling procedure. It was important to get mixed samples of the material produced on different days.

\subsection{Chemical analyzes}

Chemical analyzes of heavy metals were made in accredited lab (Estonian Environmental Research Centre) according to standard methods (shown in Table 5). Respiration activity during 7 days $\left(\mathrm{RA}_{7}\right)$ was determined with OxiTop ${ }^{\circledR}$ system (WTW, Germany) and total organic carbon (TOC) with total organic carbon analyzer (TOC-V CPH, SSM-5000A, Shimadzu) in the laboratory of Bio- and Environmental Chemistry, Estonian University of Life Sciences. All samples were sieved with a $10 \mathrm{~mm}$ sieve before running the tests. Dry matter was determined after drying samples for twenty four hours at a temperature of $105^{\circ} \mathrm{C}$.

\subsection{Describing the characteristics of the soil and the fine fraction}

Soil properties were described by using Hyprop measuring device from UMS (Umwelt Measurement Systeme, Germany). This test device is using evaporation method according to WIND/SCHINDLER for the determination of unsaturated hydraulic conductivity and water retention characteristics of soil samples [6].

\section{RESULTS}

\subsection{Chemical parameters}

Chemical properties of FF are shown in the Table 3. All the heavy metal values correspond predetermined limits set by Environmental Board [11] except zinc. High concentration of Zn 
may have occurred due to having fish industry and tinning factory on Saaremaa. In the following analysis level of zinc did not exceed the required level therefore it may have been caused by point pollution. $\mathrm{C} / \mathrm{N}$ ratio exceeded [2] showing that organic carbon had not jet mineralized in a landfill.

Table 3. Characteristics of FF

Measured

Required [10]

\begin{tabular}{lccc}
\hline Characteristic & Unit & Value & Limit value in industrial area \\
\hline Arsenic $(\mathrm{As})$ & $\mathrm{mg} / \mathrm{kg}$ & 5 & 50 \\
\hline Cadmium $(\mathrm{Cd})$ & $\mathrm{mg} / \mathrm{kg}$ & $<1$ & 20 \\
\hline Chromium $(\mathrm{Cr})$ & $\mathrm{mg} / \mathrm{kg}$ & 40 & 800 \\
\hline Nickel $(\mathrm{Ni})$ & $\mathrm{mg} / \mathrm{kg}$ & 24 & 500 \\
\hline Lead $(\mathrm{Pb})$ & $\mathrm{mg} / \mathrm{kg}$ & 220 & 600 \\
\hline Zink $(\mathrm{Zn})$ & $\mathrm{mg} / \mathrm{kg}$ & 1400 & 1000 \\
\hline Copper $(\mathrm{Cu})$ & $\mathrm{mg} / \mathrm{kg}$ & 110 & 500 \\
\hline Mercury $(\mathrm{Hg})$ & $\mathrm{mg} / \mathrm{kg}$ & 0.89 & 10 \\
\hline Carbon / Nitrogen $(\mathrm{C} / \mathrm{N})$ ratio & & 33 & $\leq 8000$ \\
\hline Respiration activity $(7$ days $)$ & $\mathrm{mgO} / \mathrm{kg} \mathrm{DM}$ & 5328 & $>80 \mathrm{~g} / 100 \mathrm{~g} \mathrm{DM}$ \\
\hline Water holding capacity & $\mathrm{g} / 100 \mathrm{~g}$ DM & 140 & -
\end{tabular}

After first analyzes it seemed to research group that according to hydraulic and chemical properties the FF had to be mixed with some additional material. Thus began to develop a mixture of the landfill cover layer which can meet all the requirements and needs the lowest possible investment in additional material.

\subsection{Hydrophysical properties of FF and biocover mixtures}

Six different mixtures of FF and amendments were used (Table 4). Locally available soil and locally available matured sewage sludge compost were used as amendments. 
Linnaeus ECO-TECH'14

Kalmar, Sweden, November 24-26, 2014

Table 4. Compositions of tested mixtures

Pos. Soil Fine fraction (FF) Matured sewage sludge

\begin{tabular}{lccc}
\hline a) & $100 \%$ & - & - \\
\hline b) & $10 \%$ & $90 \%$ & - \\
\hline c) & $17.5 \%$ & $83 \%$ & - \\
\hline c. 1$)$ & $17.5 \%$ & $83 \%$ & - \\
\hline c. 2$)$ & $17.5 \%$ & $83 \%$ & - \\
\hline d) & $25 \%$ & $75 \%$ & $20 \%$ \\
\hline e) & $20 \%$ & $60 \%$ & -
\end{tabular}

The most important indicators are infiltration capacity, porosity, hydraulic conductivity, water retention curve and its saturated and field capacity properties to assess the water percolation and retention.

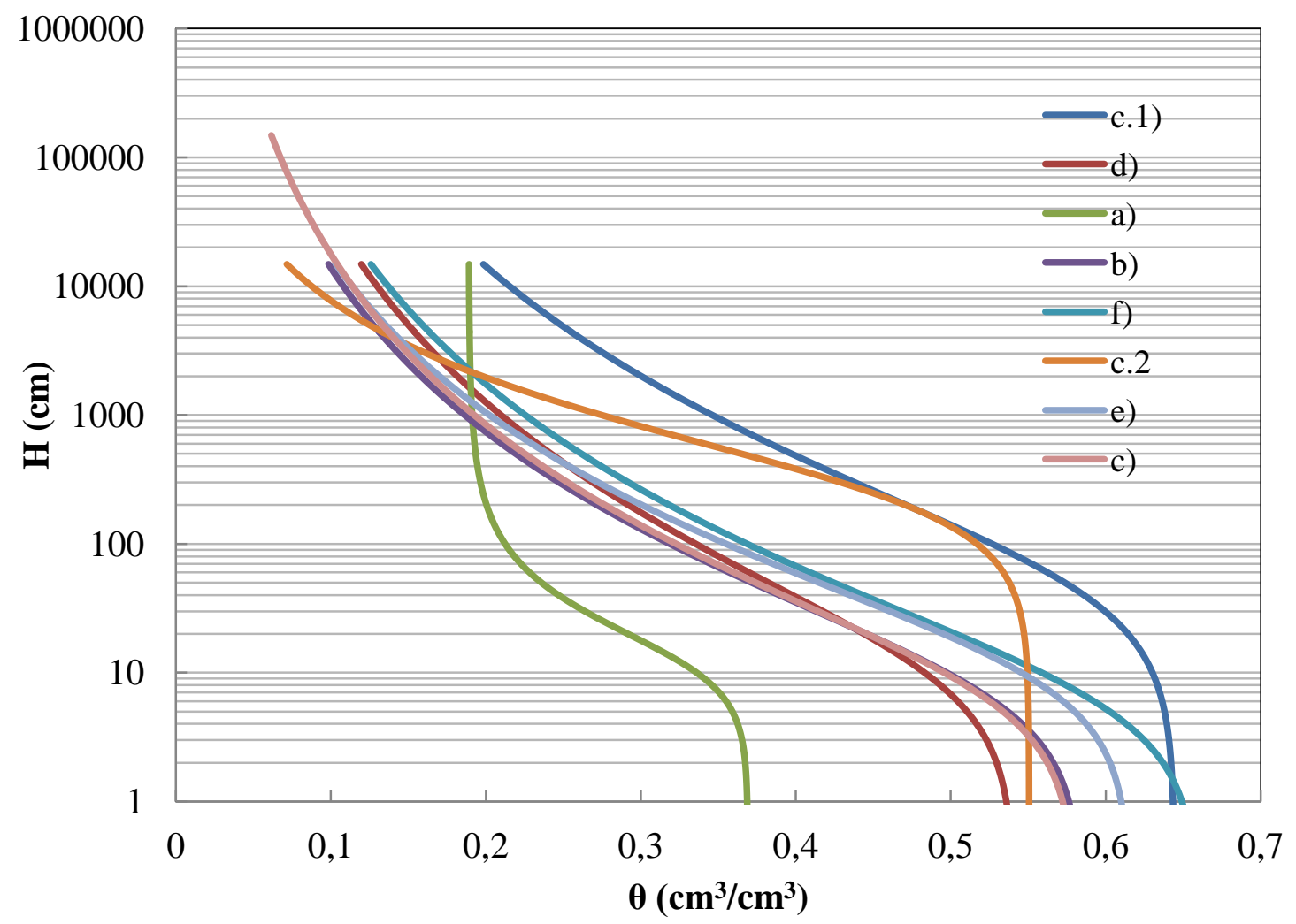

Figure 2. Water retention curves of various mixtures 


\section{Linnaeus ECO-TECH'14}

Kalmar, Sweden, November 24-26, 2014

Figure 2 reveals that the saturated water content and field capacity of soil are $0.37 \mathrm{~cm}^{3} / \mathrm{cm}^{3}$ and $0.2 \mathrm{~cm}^{3} / \mathrm{cm}^{3}$. Respectively, i.e. after complete saturation $17 \mathrm{~mm}$ of water will percolate from soil layer with thickness of $10 \mathrm{~cm}$ or vice versa the soil at field capacity may absorb up to $17 \mathrm{~mm}$ of rainfall.

Analyze of FF reveals that a porosity and water saturation capacity are significantly greater than soil, being approximately $0.65 \mathrm{~cm}^{3} / \mathrm{cm}^{3}$. Thus the $10 \mathrm{~cm}$ layer of FF can store up to 65 $\mathrm{mm}$ of water. However as the volumetric field capacity is $0.35 \mathrm{~cm}^{3} / \mathrm{cm}^{3}$ it yields with high potential percolation due to gravity flow.

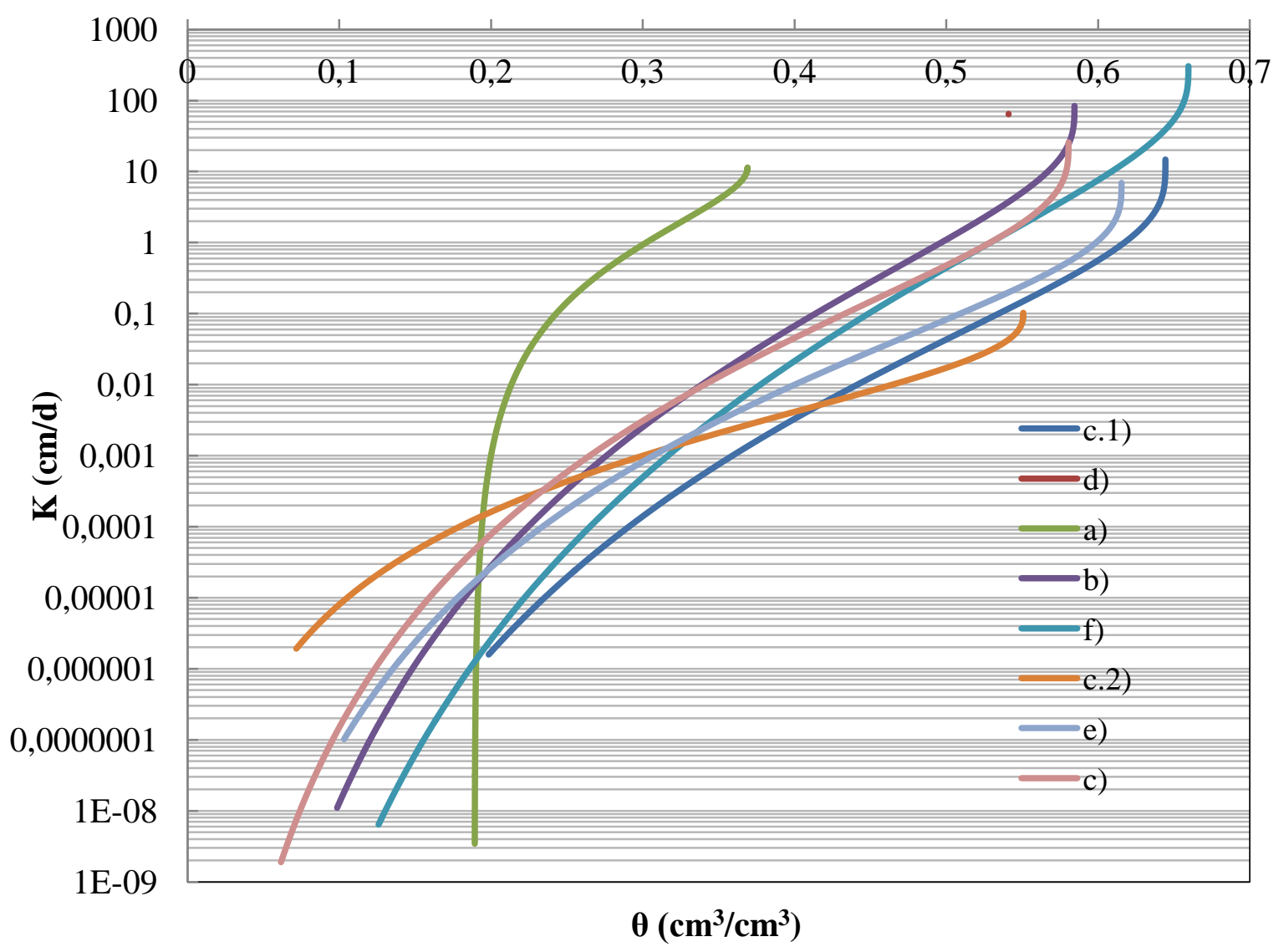

Figure 3. Hydraulic conductivity curves of various mixtures.

Analyzes showed that hydraulic conductivity of pure FF is significantly better than soil. The results are respectively $305 \mathrm{~cm} / \mathrm{d}$ and $11 \mathrm{~cm} / \mathrm{d}$. This indicator is very important because the high hydraulic conductivity means that the larger pores are released from water faster and this improves the gas exchange capability.

\subsection{Adjustment of FF to meet the values of biocover.}

Most of the tests carried out with FF showed that it was suitable for biocover. Only the C/N ration did not meet directly the requirements set by Ministry of the Environment [2]. There was a concern that perhaps the values of hydraulic properties are too high and the biocover would dry out too quickly. This could have led to the following problems: methanotrophs and 
vegetation can not adapt to a dry environment and there might be risk of wind erosion. Mixing FF with some amount of soil would decrease the hydraulic conductivity. First additional chemical analyses were made with the mixture (c), which contained $17 \%$ soil +83 $\%$ FF. The results are shown in Table 5.

Table 5. Characteristics of mixture (c).

Measured

Required [2, 11]

\begin{tabular}{|c|c|c|c|c|}
\hline Characteristic & Method & Unit & Value & $\begin{array}{l}\text { Limit value in } \\
\text { industrial area }\end{array}$ \\
\hline Total nitrogen $(\mathrm{TN})$ & ISO 11261 & $\mathrm{mg} / \mathrm{kg}$ & 3100 & - \\
\hline Petroleum hydrocarbons & ISO 16703 & $\mathrm{mg} / \mathrm{kg}$ & 2650 & 5000 \\
\hline Arsenic (As) & SFS 5074 & $\mathrm{mg} / \mathrm{kg}$ & 4.7 & 50 \\
\hline Cadmium $(\mathrm{Cd})$ & SFS 5074 & $\mathrm{mg} / \mathrm{kg}$ & 0.43 & 20 \\
\hline Chromium (Cr) & SĪJnr.M/U91 & $\mathrm{mg} / \mathrm{kg}$ & 29 & 800 \\
\hline Nickel (Ni) & SĪJnr.M/U91 & $\mathrm{mg} / \mathrm{kg}$ & 11 & 500 \\
\hline Lead $(\mathrm{Pb})$ & SĪJnr.M/U91 & $\mathrm{mg} / \mathrm{kg}$ & 49 & 600 \\
\hline Zink (Zn) & SĪJnr.M/U91 & $\mathrm{mg} / \mathrm{kg}$ & 350 & 1000 \\
\hline Copper $(\mathrm{Cu})$ & SĪJnr.M/U91 & $\mathrm{mg} / \mathrm{kg}$ & 48 & 500 \\
\hline Mercury $(\mathrm{Hg})$ & SĪJnr.M/U96 & $\mathrm{mg} / \mathrm{kg}$ & 0.43 & 10 \\
\hline Total organic carbon (TOC) & EVS-EN 13137 & $\% \mathrm{DM}$ & 5.1 & $>8 \%$ \\
\hline Carbon and nitrogen $(\mathrm{C} / \mathrm{N})$ ratio & - & - & 27 & 15 \\
\hline
\end{tabular}

In the terms of pollutants concentration the mixture (c) was suitable for methane degradation layer. Results did not meet the limit values of total organic carbon (TOC $=5.1 \%$; required > $8 \%)$ and carbon / nitrogen ration $(\mathrm{C} / \mathrm{N}=27$; required $\mathrm{C} / \mathrm{N}=$ ca 15$)$. Therefore research group decided to add matured sewage sludge to mixture (pos e, Table 4).

Next chemical analyses were made with the mixture (e) which contained $60 \% \mathrm{FF}+20 \%$ soil $+20 \%$ sewage sludge. According to the analyses made in the Estonian University of Life Sciences Biotechnology and Environmental Chemistry laboratory the mixture (e) fulfills the prescribed parameters of the coating mixtures. The results are shown in Table 6 . 
Table 6. Characteristics of mixtures (e)

Measured $\quad$ Required [2]

\begin{tabular}{lccc}
\hline Characteristic & Unit & Value & Value \\
\hline Dry matter content & $\%$ & 67.1 & - \\
\hline $\begin{array}{l}\text { Respiration activity }(7 \\
\text { days })\end{array}$ & $\mathrm{mg} \mathrm{0} / \mathrm{kg}$ & 5488 & $\leq 8000$ \\
\hline TOC & $\% \mathrm{DM}$ & 7.7 & $>8$
\end{tabular}

There was very high probability that substitution of $20.0 \%$ FF-material with sewage sludge would not have increased the heavy metal content. Therefore it was not considered useful to make new chemical analyzes of pollutants. The tests carried out with Hyprop measuring instrument had shown that the mixture (e) can absorb a large quantity of rainwater $(0,61$ $\left.\mathrm{cm}^{3} / \mathrm{cm}^{3}\right)$. Field water capacity is $0.35 \mathrm{~cm}^{3} / \mathrm{cm}^{3}$ therefore a large proportion $(0.61-0.35=$ 0.26) saturated water content drain off. Based on the test results it was decided to use the mixture (e) for Kudjape landfill methane degradation layer. This version consisted of $60 \% \mathrm{FF}$ $+20 \%$ soil $+20 \%$ of sewage sludge.

\section{CONCLUSION}

There has been very little research in the world about suitability of the fine fraction excavated from landfill as methane degradation layer. It was important to study the chemical properties as well as and hydrophysical properties of the material in order to assess its suitability as biocover. Although properties of FF were within prescribed limits, there were some doubts that FF in general may still be too active in terms of respiration activity. Mixing FF with soil would allow to decrease the hydraulic conductivity. It was necessary to study the best ratio of various components in tested mixtures to achieve all the predetermined characteristics.

According to the study the FF screened from Kudjape landfill was suitable for constructing biocover. In the current study, mixture in the following ratio was used: $60 \% \mathrm{FF}+20 \%$ soil + $20 \%$ of sewage sludge. Elsewhere, other ratios may be justified and it is recommended to mix the FF with soil.

It is recommended to decide upon mixtures according to hydrophysical properties and respiration activity. Only in final decisions perform more costly chemical analyzes.

The installation of the methane degradation layer has been finished. The research group will continue to monitor the result of methane degradation in full scale. Transferring research findings into another landfill must be remembered that the properties of the covering layer and the mixture ratios are strongly dependent on the mixture of sieved material and the properties of the landfill.

\section{Acknowledgements}

Swedish Institute, Kudjape landfill personnel, 


\section{REGERENCES}

[1] Cheremisinoff, N. P., (2003). Handbook of Solid Waste Management and Waste Minimization Technologies. pp 101; 113

[2] Environmental Board.(2011). Regulation. HLS 1-15/11/398. Haapsalu

[3] Humer, M., \& Lechner, P., (2001). Design of a landfill cover layer to enhance methane oxidation results of a two year field investigation. Proceedings Sardinia 2001, Eighth International Waste Management and Landfill Symposium.

[4] Humer-Huber, M., (2008). Technischer Leitfaden. Methanoxidationsschichten. Wien.

[5] IPCC, 2007: Climate Change 2007: Mitigation. Contribution of Working Group III to the Fourth Assessment Report of the Intergovernmental Panel on Climate Change [B. Metz, O.R. Davidson, P.R. Bosch, R. Dave, L.A. Meyer (eds)], Cambridge University Press, Cambridge, United Kingdom and New York, NY, USA., pp 28

[6] Hyprop. (2012). User Manual.

[7] NSW. Passive Drainage and Biofiltration of Landfill Gas using Recycled Materials.

[8] NSW, T. U., (2010). Handbook for the design, construction, operation, monitoring and maintance of a passive landfill gas drainage and biofiltration system.

[9] Oonk, H., (2010). Literature review. Methane from landfills. Methods to quantify generation, oxidation and emission pp 8-9.

[10] Pedersen, G. B., (2010). Processes in a compost based landfill biocover;methane emission, transport and oxidation.

[11] RTL 2004, 56. 938. (Last downloaded 10.10.2014). https://www.riigiteataja.ee/akt/748981.

[12] Solomon, S., (2007). Climate Change 2007 - The Physical Science Basis. pp 33. 